\title{
A social revolution in the name of a religion? The Islamic Revolution of 1978/79 in Iran
}

\author{
Amir SHEIKHZADEGAN ${ }^{1}$
}

University of Fribourg

\begin{abstract}
The year 1979 witnessed an event that was to impact the world for decades to come. The Western-friendly monarchic regime of Iran that had pushed through a rapid modernization program by leaning on a repressive security apparatus was toppled by a nationwide protest movement and replaced by an Islamist regime.

This study delivers, from a historical sociological perspective, an analysis of the major factors that led to this major transformation of Iranian society. The focus lies thereby on the dialectical interplay of endogenous and exogenous factors including imperialist interventions, a rentier state, a social split, a supply crisis, radical ideologies and the dynamics of a Shite community.

Key words: revolution, Iran, Islam, Shiism, Islamism, the Shah, Ayatollah Khomeini
\end{abstract}

Between 1978 and 1979 a political event propelled political Islam onto the global stage, thus impacting the world society for decades to come: In a nation-wide movement led by a cleric called Ayatollah Ruhollah Khomeini, the monarchic regime of Iran ruled by Mohammad Reza Pahlavi (hereinafter: the Shah/the monarch) was brought down and replaced by a regime that claimed to restructure Iranian society after the tenets of Shiite theology.

Whilst Iran under the Shah was "one of America's best, most important, and most loyal friends in the world" (Kissinger 1979: 1262; cited in Brown 1994: 352), the revolution of 1978/79 turned this proximity into an endless animosity. But what caused this sudden and radical change in Iranian politics?

Applying the method of historical sociology, this study renders an analysis of the circumstances that a) gave rise to the revolution and b) led to the installation of an Islamist regime. In order to adequately deal with these questions, the study proposes the following two theses:

Thesis 1: In order to explain the sparking of the Iranian Revolution, one should take into account the interplay of endogenic and exogenic factors, thereby analyzing, on each side of the interaction, both structural and cultural/ideological factors.

\footnotetext{
${ }^{1}$ Amir Sheikhzadegan, Dr., University of Fribourg, Department of Social Sciences, Route des Bonnesfontaines 11, CH1700 Fribourg, amir.sheikhzadegan@unifr.ch. Sheikhzadegan is a senior researcher in the field of sociology of religion. His research interests include Islamic radicalism, Muslims' civic engagement, Muslim spiritual care, conversion to Islam, identity research and societal change in contemporary Iran.
} 
Thesis 2: In order to explain how Khomeini and his men were able to give the revolution an Islamist direction one should go beyond Thesis 1 to also analyze the strategies deployed by both the Shah and the Islamists.

Keeping these two theses in mind, the contribution is structured as follows. After giving a short review of the state of the art, the article deals in two consecutive sections with an analysis of the exogenic and endogenic factors of the revolution. Since the Iranian Revolution was articulated in religious terms, special attention is paid to the question of culture and ideology. Therefore, it is spared out to be discussed in a separate section. Having rendered an account of what sparked the revolutionary process, the contribution deals in a following section with the second thesis by discussing the question of how the Islamists managed to appropriate the revolution for their political agenda. In a last section the insights gained hitherto are summarized. Finally, some concluding remarks wrap up the contribution.

\section{State of the art}

In this section I give a short review of the studies of revolutions in general terms and then focus on the studies of the 1979 Revolution.

\section{Studies of revolutions}

In the 1980s, Goldstone (1980; 1982) suggested that in the bulk of studies of revolutions three generations could be identified: The first generation of scholars of revolution - the so-called natural history school - focused on a precise description of the process of the revolutions in question without theorizing the factors leading to them. The second generation of studies was dominated by the modernization school of the 1960s and delivered social psychological and functionalist explanations of revolutions - the most influential of which was Davies' (1962) J-curve model, known also as the theory of rising expectations. The third generation, mostly comparative studies, applied a Marxist perspective to analyze the structural vulnerabilities of regimes as the main causes of revolutions.

Drawing on Goldstone's three-generation typology, Foran (1993) has suggested that since the 1980s a fourth generation of studies has emerged with interest in the themes neglected in earlier studies of revolutions, including the role of agency, culture and ideology. This observation has also been shared by Goldstone (2001) himself who has referred to a shift in the focus of newer studies toward "leadership, ideology, and processes of identification with revolutionary movements as key elements in the production of revolution" (Goldstone 2001: 139).

In the same spirit, Bornschier (2008) has argued that explanations of revolutions should go beyond structural factors to also consider the role of ideas and values. He has also suggested classifying the values and aspirations expressed in a revolution into three main types: yearning for equality (socialist revolutions), freedom (the revolutions in Eastern Europe against communist regimes) and security (anti-modernist revolutions).

As it will be shown, a broadening of the scope to include both structural aspects and issues concerning culture, agency and ideology is of special merit when it comes to an explanation of the causes of the Iranian revolution. 


\section{Studies of the Iranian Revolution}

The Iranian revolution caused much anxiety among scholars of revolution, as it was the first revolution to be launched in the name of Islam and against a modernist, pro-Western regime. Skocpol (1982), a prominent third-generation theoretician of revolution was one of the first to acknowledge that an explanation of the Iranian revolution had to go beyond an analysis of the social tensions created by structural factors (which she saw in the intrinsic contradictions of a rentier state) to also consider the Shiite aspirations of Iranians - namely "the popular messianic yearning for the return of the Twelfth Imam" (Skocpol 1982: 277).

Abrahamian (1982b; 1989; 2001) has highlighted both structural and political factors to explain the Iranian Revolution. On the one hand, he has pointed out that the structural tensions of a rentier state had weakened the regime to an extent that it was destabilized by two "relatively minor blows" (Abrahamian 1989: 28), namely the economic crisis and the international pressure to ease its repressive system. On the other hand, he sees the main causes of this revolution in the political vacuum created by the repression of secular opposition as well as in the leadership of Ayatollah Khomeini - through his charisma, religious authority and ability to tap into the socioeconomic grievances of the lower and middle classes. ${ }^{2}$

Generally speaking, scholars agree on the notion that both the weakness of the Shah and the determination of the revolutionary forces were instrumental in bringing about the Iranian revolution. Arjomand (1988), for instance, sees the reasons for the downfall of the Pahlavi regime primarily in "its loss of legitimacy and a massive nationwide campaign of civil obedience" (Arjomand 1988: 191). A focus on the question of legitimacy can also be found in the comparative study of the revolutions of Mexico, China and Iran by Ingold (2016).

In her comparison of the Nicaraguan and Iranian revolutions, Farhi (1990) has suggested that Skocpol's structural theory of revolutions be elaborated by integrating the role of ideology, the changing balance of class forces in an uneven development, and the internal dynamics of states in "peripheral formations" (Farhi 1990; cited in Foran 1993: 13).

In his comparative analysis of social revolutions in Iran, Nicaragua and El Salvador, Foran (1990; cited in Foran 1993: 13) has argued that a "dependent development" (Cardoso/Faletto 1979; cited in Foran 1993: 13) creates over time a disharmony between overall economic gains and disadvantages for a broad range of social classes, which can only be upheld through repressive systems. In such a political system a revolution occurs, if there is a) a political culture of opposition, b) opposition leaders have the capacity to organize an upheaval, and c) there emerges an internal economic crisis accompanied by a world-system opening (see also Foran 1993: 13-14). In a similar world-system approach Gerami (1989) and Sheikhzadegan (2003; 2005) have argued that the Iranian Revolution was caused by the interplay of internal and external factors.

Finally, Käufeler (1988) has argued that while economic grievances of a majority of the Iranian people played an important role in the Iranian Revolution, it was "in a substantial sense a 'Cultural Revolution"” (Käufeler 1988: 278), as its dominating narrative was that of an upheaval of Islam against modernity.

\footnotetext{
${ }^{2}$ For the crucial importance of the leadership of Ayatollah Khomeini, see also Dabashi (1989).
} 
The present paper draws on the insights of these and other earlier studies while integrating the most recent historical findings and theoretical contemplations and gives a) a more nuanced account of the dialectics of endogenic and exogenic factors and the interplay of structure, culture, ideology and agency, and b) a more systematic differentiation between the causes of the revolution and those of its Islamization.

\section{The exogenic factors}

Drawing on Bornschier's analysis of the relevance of "outer space" (2008: 459-462) for a revolution, the impact of the world system on the Iranian revolution can be broken down into three dimensions: culture, economics and politics.

\section{Political dimension}

In 1979 Ayatollah Khomeini called the USA the great Satan, thereby tapping into deep-rooted anti-imperialist sentiments of the Iranians. Indeed, from the nineteenth century on, Iran's lot has constantly been affected by foreign interference. First, the colonial powers of Russia and the UK as well as the Ottomans penetrated the country, exploiting its resources and crippling its institutions. Then there came the occupation of the country during World War I (by the British and the Russians) and World War II (by the Allied forces) with devastating impacts on both the sovereignty and the economy of the country.

By far what had the biggest impact on the 1979 Revolution was, however, Mosaddeq's cause for the liberation of Iranian oil from British control at the turn of the 1950s. The more enthusiastic the Iranian people were of Mosaddeq's charismatic leadership and his steadfast resistance against the British, the more depressed and angry they became, as in 1953 the USA, the UK and the royalist forces successfully launched a military coup against the popular prime minister. Mosaddeq's downfall not only put an end to the nationalist aspirations of the Iranians, but also disrupted a unique experiment of democracy and rule of law. Moreover, in the eyes of many Iranians, the USA turned overnight from friend to foe. In the words of Abrahamian (2001: 213):

The coup tarred America with the British brush: being perceived as the "colonial power," a perception that created deep distrust between Iran and United States. It set up a dictatorship that became increasingly unpopular and corrupt. It put a nail in the coffin of the same monarchy by inseparably linking it to the imperial powers. It discredited the army by identifying it with the shah, the CIA, and the MI6. It destroyed the secular parties both the Tudeh and the National Front - and so paved the way for the emergence of Khomeini's religious opposition.

The coup also meant a forceful integration of Iran into the new political structure of the world society (Bornschier 2008), in which an increasing number of less developed countries were organized as dependent satellites of either the capitalist or the socialist camp. Aligned with the Western pole, the monarch enjoyed extensive support of the USA (be it in financial, military, 
consulting, intelligence or political regard) and could thus successfully build up an authoritarian rentier state (Skocpol 1982; see also Boroujerdi 1996).

Of immediate relevance for the 1979 Revolution were also a number of short-term political impacts caused by the world system, including the following:

Firstly, in the second half of the 1970s the Shah stood under enormous pressure not only by the human-rights policy of President Carter (1976-1980) but also by the Western media and international human-rights groups that criticized him for human rights abuses (see Keddie 2003: 215). ${ }^{3}$ This was the main reason why in 1976 the Shah launched a policy of political opening. By doing this, he made the first crack in the wall that led, two years later, to the outburst of the revolution. ${ }^{4}$ The relevance of political opening for the 1979 Revolution reminds one of Tocqueville's following famous quote: "[...] when a people which has put up with an oppressive rule over a long period without protest suddenly finds the government relaxing its pressure, it takes up arms against it" (Tocqueville 1955: 230). ${ }^{5}$

Secondly, Ayatollah Khomeini's exile from Iraq to Paris on October 6, 1978 gave him unprecedented access to the global media. In the burgeoning of the postmodern era, the exotic image of an old Muslim cleric sitting under an apple tree in Neauphle-le-Château ${ }^{6}$ and fighting against the unpopular autocrat in Tehran and American imperialism must have been irresistible to the Western media and intellectuals. ${ }^{7}$ Reports from the global media were conveyed in Iran through diverse channels, the most important of which was the Persian program of BBC Radio that, thanks to short wave radios, could be received even in rural areas of the country. These communication opportunities gave Khomeini an enormous advantage over the oppositional leaders in Iran, who suffered from censorship and were furthermore hindered by a ten-week strike of the Iranian press (Sheikhzadegan 2003). ${ }^{8}$

\footnotetext{
${ }^{3}$ For the impact of "perceived removal of strong support for the repressive practices of a dictator" on the success of a revolution, see Foran (1993: 6).

${ }^{4}$ According to Keddie (2003: 215), the Shah was not only pressured by Carter and the Western human-rights organizations to loosen up his repressive system, but also by the following personal concern: As he secretly suffered from cancer, he presumably believed that his successor would not be capable of ruling the country as rigidly as he himself and that a political opening would be therefore the best way to ensure the continuity of his dynasty.

${ }^{5}$ Challenging the Tocquevillean thesis that social movements erupt when a weakening of the state coincides with the public's awareness of opportunities to stand up against the state, Kurzman (1996) has argued that at the eve of the Iranian Revolution the state structure was very strong, and that therefore the sparking of the revolution muss be rather ascribed to the strength of the opposition than the weakness of the state. While sharing with Kurzman the notion that the Iranian state structure was remarkably strong, I argue, as amply demonstrated in this contribution, that the relevance of the political opening of the regime for the revolution cannot be underestimated.

${ }^{6} \mathrm{~A}$ small French town near Paris.

${ }^{7}$ The most renowned postmodernist intellectual fascinated by the Iranian Revolution was indeed Michel Foucault (See Afary/Anderson 2010).

${ }^{8}$ As Khomeini's presence in Paris coincided with the strike of the Iranian press, which lasted from November 6, 1978 up to January 16, 1979, he advanced, during this period, to the undisputed leader of the movement. Thus, after the end of the strike, the press referred to Khomeini with much loftier words than before. For instance, Ettelaat - one of the two widest-read newspapers in Iran - abandoned the phrase mosallas-e rahbari (the triad of the leadership) to refer to Ayatollah Shariatmadari and his two other peers, Golpayegani and Mar' ashi Najafi, while Khomeini was addressed by the revered title emam (the Imam). Moreover, every word from or about Ayatollah Khomeini appeared in big print on the first page, while news regarding the other leading clerics were put in small print somewhere in the inner pages (see Sheikhzadegan 2003: 217-218).
} 


\section{Cultural dimension}

An important feature of the Revolution of 1979 was the predominance of utopian ideals in the political discourse of the time. More specifically, the younger generation was attracted to ideologies that aimed at a substantial restructuring of the society by violent means. These radical tendencies were not only a reaction to the repressive practices of the regime, but also inspired by revolutionary impulses from the world system. As Jahanbegloo has remarked:

Fanon's nativist philosophy and his idea of violence as a 'cleansing force' and the guerilla warfare experiences of Ernesto Che Guevara, Castro and others in Latin America [...] opened the door to a new wave of romanticization of violence as an approach to political struggle in Iran (Jahanbegloo 2017: 27).

Even though the revolution was the result of a mass, peaceful movement, the monarchic regime was only toppled after the leftist, guerilla organizations, together with militant religious groups and pro-revolutionary factions of the army, attacked the military barracks and defeated the elite Imperial Guard (Keddie 2003: 238). Furthermore, the uncompromising stance of the revolutionaries towards the monarch resulted from their utopian ideals and their demonization of the Shah as the symbol of decadent Western capitalism. The most violent expressions of political ideologies devolved, however, in the first post-revolutionary years, as military conflicts outburst between the Islamist militias, on the one hand, and the dissident guerilla organizations and radical ethnic movements, on the other. Finally, Khomeini masterfully mobilized the violent potential of the Islamist youths during the Iran-Iraq war.

Another feature of the cultural impact of the world system was indeed the rapid diffusion of Western/American lifestyles among the urban middle and higher classes. This cultural change deepened the existing social split between the modern and the traditional social strata and compounded class tensions with a cultural dimension. The rise of nativism in the 1960s and its evolution to Islamism can partly be explained by this cultural conflict.

\section{Economic dimension}

The overwhelming dependence of the Iranian economy on oil export revenues made it quite susceptible to the world-market prices for oil. Indeed, it was the overheating of the Iranian economy in the aftermath of the 1973 oil crisis that led to its destabilization. The oil export revenues of the country rose from 2.5 billion US\$ in 1972 to 5.1 billion US\$ in 1973 and 18.7 billion US\$ in 1974 (data extracted from Daneshkhu 2004: 391). In 1976, Iranian oil exports made up $97.5 \%$ of its total commodity exports, $88.4 \%$ of its total exports of goods and services and 34.9\% of its GDP (Looney 1982: 91). Regarding these impressive figures, a cautious economic strategy would have been required to counter the negative impacts of these new financial resources on the economy:

A prudent economic management of such large external funds would suggests [sic] a gradual and planned infusion of the new oil revenues into the Iranian economy. The remaining funds could have been invested abroad for future use and as a buffer against weak global economic conditions and lower oil prices (Mohaddesa/Pesaran 2012: 10). 
However, the Shah decided to immediately spend the unexpected national wealth domestically. This "enabled the government not only to balance the books but also to embark on its bigpush drive by revising the Fifth Plan to increase expenditure by 90 per cent, from 2,486 billion rials to 4,697 billion rials" (Daneshkhu 2004: 135). The infusion of such amounts of new resources into the economy led to a sharp increase in demand, which in turn caused an acute supply crisis (see the next section). As the ambitious development strategy of the Shah would have required a constant increase in oil revenues, the stabilization of oil prices in the world market in the mid-1970s seriously hampered these plans, thus aggravating the already unleashed economic crisis (Daneshkhu 2004: 135; see also Looney 1986).

\section{The endogenic factors}

The endogenic factors that gave rise to the nationwide protest movement against the monarchic regime were more complex, manifold and multi-facetted. In the following the most appalling of these factors will be sketched.

\section{A contradictory and unadapted modernization program}

The development strategy of the Shah was based on the wisdom of the mainstream US economists of the time. In the words of Looney, "[t]he creation of a prosperous, healthy, literate, well-housed, and largely (90 percent) urban society was the strategy's ultimate objective with industry emerging as the employer of perhaps 40 percent of the labor force" (Looney 1982: 264). The strategy failed not only because its implementation showed serious flaws, but also because it completely excluded the Iranian people from any decision-making process whatsoever. Moreover, there was no attempt to adapt the modernization program to the cultural and structural characteristics of Iranian society.

Iran's "uneven development" (Abrahamian 1982b: 419-449) was not only manifested in the discrepancy between socioeconomic development and political underdevelopment, but also in the

discordant combination of cultural freedoms and political despotism - of increasing censorship against the opposition but increasing freedoms for everyone else. It is far from hyperbole to claim that during the sixties and the seventies, Iran was one of the most liberal societies in the Muslim world in terms of cultural and religious tolerance, and in the state's aversion to interfere in the private lives of its citizens - so long as they did not politically oppose the Shah (Milani 2011:335).

Cultural liberalism was best demonstrated in the annual Shiraz Art Festival, in which artists of international fame including those at the forefront of the Western avant-garde (such as Karlheinz Stockhausen, John Cage, Peter Brook, Maurice Béjart, Iannis Xenakis, etc.) were invited to present their art. 


\section{Supply crisis}

As already mentioned, a sharp rise in demand, with the supply lagging far behind, led in the 1970s to an acute shortage of goods and services. The reasons were manifold. As for the demand side, a rapid increase of liquidity resulting from the multiplication of oil revenues and the emergence of a consumer society after the Western model can be highlighted. Of major impact were also demographic factors (Hourcade 1983; 1993). On the one hand, the land reforms introduced in the 1960s accelerated, paradoxically enough, the migration of the rural population to the cities (Looney 1982: 56). ${ }^{9}$ On the other hand, the Iranian population showed, due to a sharp reduction in infant mortality, a rapid growth rate, rising from 18.9 million in 1956 to 33.7 in 1976 (Sheikhzadegan 2005). The confluence of population growth and rural-urban migration led to an increase in the urban population from 5.9 million in 1956 to 15.8 million in 1976, which meant a growth from $31 \%$ to $47 \%$ of the total population of the country (Sheikhzadegan 2005).

As for the supply side of the equation, infrastructural bottlenecks such as ports, transportation and power (Looney 1982: 128) hampered the production or import of goods and services. The port infrastructure could hardly cope with the increasing imports, thus affecting the price of imported goods, as shipping companies charged the importers for the long waiting time at the overcrowded Iranian ports. Moreover, the released goods faced an underdeveloped transportation system. These shortcomings not only hampered the distribution of imported goods, but also exacerbated domestic manufacturing by slowing down the delivery of raw material, machineries and spare parts. The power shortages led to recurrent blackouts that worsened the functioning of factories and other production sites, not to mention their negative impact on private households and the jammed streets of major cities.

Domestic production sites also suffered from a shortage in manpower, especially when it came to skilled workers (such as machinists, masons, painters, plumbers, electricians etc.), as well as legal insecurities, a lack of raw material as a result of a decline in agricultural production, and a lack of investment, as only a negligible part of the large oil revenues were channeled into domestic manufacturing. ${ }^{10}$ The imbalance between supply and demand caused high rates of inflation so that the cost-of-living index rose "from a base of 100 in 1970 to 160 in 1975, and further to 190 in 1976. The rise was even steeper for such essentials as food and housing" (Abrahamian 1989: 28). Such inflation rates caused much pain and discomfort for a vast part of the population. Even though the Iranian revolution was too complex to be reduced to a single factor, the rising expectations theory of Davies (1962) can explain to some

\footnotetext{
${ }^{9}$ Looney mentions three reasons why the land reform hastened the migration of the rural population to the cities. Firstly the most fertile lands were excluded from distribution and remained in the hands of the big landlords, and the less productive lands distributed among the nasaq-dar (tenants) were often too small to be productive. Therefore, the new owners of those parcels preferred to sell their lands and to migrate to the cities. Secondly, the so called khoshneshin-ha (rural workers) were excluded from land disruption and lost their jobs, as the distributed lands were too small to absorb them. So they had no other option than to migrate to the cities. Thirdly, the offshoot of the better-off peasants preferred to live in the cities which were much more attractive and offered many more opportunities and social services including schools, jobs, medical services and leisure time activities (see Looney 1982: 54-56; Sheikhzadegan 2003, chapter 7).

${ }^{10}$ As Looney has remarked, "in general, oil revenues were utilized more efficiently for consumption (a large part of domestic absorption) than investment purposes and that their impact on private sector investment spending was minimal compared to that of the government" (Looney 1982: 111).
} 
degree the public discontent that led to the 1979 Revolution (see also Mohaddesa/Pesaran 2012: 10). ${ }^{11}$

In order to contain the inflation, the Shah declared war on "profiteers" (Abrahamian 1989: 28) by deploying thousands of students to identify and even arrest price-abusing businessmen (Milani 2011: 336-337). With this policy the monarch not only intended to bypass the inefficient and corrupt state bureaucracy, but also to exhaust the revolutionary, anti-capitalist zeal of the students. The anti-profiteering campaign of the regime, however, "sowed the seeds of distrust and resentment of the government by the bazaar ${ }^{12}$ and at the same time received and harbored the historical alliance of the ulma [sic] and the bazaar" (Looney 1982: 167). As Abrahamian has remarked, there were hardly any bazaar families that did not suffer from sanctions by price supervisors (Abrahamian 1989: 29). The regime also declared war on unlicensed retail trade, thus persecuting thousands of migrants from rural areas who earned a living as street vendors of fruits and vegetables (Sheikhzadegan 2003).

\section{Mass rural-urban migration}

One of the most conspicuous manifestations of an "uneven development" (Abrahamian 1982b: 419-449) in Iran was indeed the demise of the rural society and the subsequent mass migration of the rural population into the cities. This demographic phenomenon was caused, on the one hand, by the land reforms (which were deficient both in planning and implementation) and, on the other hand, by an overt urban bias in the overall development strategy of the regime, leading to a concentration of public facilities and services in the urban areas. As Looney has remarked, "[t]he land reforms effectively undermined the village system of organization, but the government did not attempt to shape developments in the rural areas to an overall strategy or plan" (1982: 58).

The mass migration of the rural population to the cities not only aggravated the supply crisis, but also led to serious social tensions. ${ }^{13}$ Firstly, the deeply traditional newcomers were by no means prepared for the Western lifestyles prevailing in the cities, which were, in their eyes, gross violations of moral values - the more so when it came to sexual relations. Secondly, they were despised by the modern urban population for their traditional lifestyles. Thirdly, as

\footnotetext{
${ }^{11}$ For the relevance of the deterioration of income distribution for the public discontent at the eve of the revolution, see Looney (1982: 265).

${ }^{12}$ Bazaar, the Persian equivalent to the suq (trade center) in Arab countries, has been for centuries the traditional commerce center in Western and Central Asia. As for the Iranian bazaar, it is "a unified, self-contained building complex of shops, passageways, and caravanserais, interspersed with squares (meydān), religious buildings, bathhouses (hammām), and other public institutions. [...]" (Bonine 1989). One distinct feature of the shops in a bazaar is that they engage both in retail and wholesale trade and play therefore a crucial role in the distribution of domestic or imported goods all over the country. Besides its economic function, however, bazaar has also played a crucial role in the cultural, social and sometimes political life of the respective city. Ashraf (1989) summarizes the functions of bazaar as follows: "The bāzār in the Islamic city has been (1) a central marketplace and craft center located in the old quarters of the town; (2) a primary arena, along with the mosque, of extrafamilial sociability; and (3) a sociocultural milieu of a traditional urban life-style. The bāzār in contemporary Iran has performed two more roles of great significance; (4) a socioeconomic and power base of the Shi ite religious establishment; and (5) a bastion of political protest movements" (Ashraf 1989. See also Scharabi 1985; Floor 1989).

${ }^{13}$ The increasing presence of the migrants from rural area in the cities was soon reflected in the Iranian cinema, literature, pop music and even religious rituals (see Sheikhzadegan 2003, chapter 8).
} 
non-skilled laborers they could but occupy positions in the lowest ladder of the social hierarchy, thus making up the bulk of the urban sub-proletariat. The marginalization of the migrants was also reflected in the morphology of the cities as they could only reside in the cheaper neighborhoods or even in the shanty towns at the outskirts of the cities, with the latter being a constant target of destruction by the urban authorities for being illegal.

\section{Socialsplit}

The Iranian Revolution was without doubt a social revolution in the sense Skocpol has suggested, namely a "rapid, basic transformation of the state, class structure and the dominant ideology" (Skocpol 1982: 265) through a class-based upheaval from below. It was a revolt of the urban lower and middle classes against Westernized elites, including the monarchic clan, state bureaucrats, high ranking staff of the security forces, and major domestic capitalists and foreign investors, all tied together in a neo-patrimonial, patronage system (Goldstone 1982; 1986). A deep structural divide dissociated those at the top from all the rest (Looney 1973: 126; Schulze 1994: 279-280; Sheikhzadegan 2003: 171-175).

At the eve of the revolution almost every social group was resented in one way or another by the policies of the regime. The students complained about the lack of political freedom and the recurrent, heavy-handed intervention of the anti-riot police on the university campuses; the bazaaris ${ }^{14}$ resented the aggressive price-policing; the clergy condemned what they regarded as moral decadence; the migrants were marginalized and despised for being ommol (oldfashioned), dehati (villager) or bisavad (illiterate). Even the westernized middle classes were disillusioned by the supply crisis and the steady ruralization of modern cities (Sheikhzadegan 2003). Moreover, the rocketing inflation affected not only lower-income families but also vast parts of the middle classes.

As Keddie has remarked:

By 1977 an economic recession, inflation, urban overcrowding, government policies that hurt the bazaar classes, glaring income gaps, and conspicuous Western-style consumption by the elite and the lack of political freedom or participation were all widely felt and belied the numerous official predictions that the 'Great Civilization' was just around the corner (Keddie 2003: 168-69).

Since the Shah's rule was a "personalist authoritarian" (Farhi 1990; cited in Foran 1993: 4) one, he alone was held responsible for all the failures of his regime.

\section{Repression system}

The impressive security forces of the regime, propped up by the skyrocketing oil revenues, ${ }^{15}$ turned out to be a trap for the Shah's rule, as their tight hold on public opinion left the Shah under the illusion that his subjects were happy with his ruling style. Therefore, he was taken

\footnotetext{
${ }^{14}$ The Persian word bazaari denotes the collective of social classes related to bazaar (see Keddie 2003: 30).

${ }^{15}$ According to Brown (1994: 356), "[f]rom 1973 to 1977 more than a third of all U.S. military sales were to Iran, whose military budget rose fourfold during this period".
} 
by surprise when in 1978 an uncompromising, mass upheaval set out to topple his regime and destroy his entire state apparatus.

Due to a complete lack of transparency of state matters, there was no public insight into the challenges facing the state. Therefore, the regime could by no means count on the patience of the people when it came to shortcomings. As a matter of fact, the people were not even asked to be acquiescent. They just had to be grateful to their wise king for leading the country towards tamaddon-e bozorg (the great civilization). Moreover, the complete lack of political freedom let no room for a national dialog over the grievances of the people. As a result, the Shah had no possibility of recognizing early signs of public discontent.

Finally, it was partly due to the hard-handed repression of any protest movements following the coup of 1953 that the moderate oppositional groups were gradually sidelined by the radical ones. With that, calls for political reforms were also lost in the outcry for a revolution.

\section{The role of media}

Similar to the role of the telegraph in Iran's Mashruteh (Constitutionalist) Revolution (190511), radio, newspapers and audio cassettes were used as key networking tools among revolutionaries in 1978/79. As for radio, the small battery-driven radios were instrumental in conveying Persian BBC programs to the most remote areas which would - because of lacking of electricity - have been otherwise inaccessible by broadcasting. Thus the whole nation was constantly exposed to the reports of news of the movement (strikes, demonstrations, death and injury tolls, etc.) as well as to the interviews with the leaders of the movement. Newspapers had a similar function, though somewhat limited, as they were mostly available in the urban areas and only accessible to the literate, not to mention the limitations caused by censorship. Audio cassettes were used on a large scale to distribute the speeches of the grand ayatollahs around the country. Finally, telephone eased interpersonal networking thus bringing the news of the movement on an informal basis across the country.

\section{Shah's inconsistent tactics}

It is difficult to say how the revolutionary movement would have evolved, had the Shah reacted differently to the ongoing events. What can be said without a doubt is that his tactics to cope with the movement were inconsistent and, therefore, counterproductive. ${ }^{16}$

To begin with, the harsh intervention of the security forces against the peaceful demonstrations led to an escalation of the conflict. Furthermore, had the Shah complied with the demands of Ayatollah Seyyed Kazem Shariatmadari and other moderate oppositional leaders to persecute the police officers for their excessive and unlawful use of force, the movement might have lost its momentum at the very beginning. To make matters worse, the Shah started to make concessions by constantly changing Prime Ministers, which was interpreted as a sign of weakness, thus strengthening Khomeini's resolve to overthrow the regime (Keddie 2003: 236-238).

\footnotetext{
${ }^{16}$ As recent research (Milani 2011) has shown, from the early 1970s having cancer had already exacerbated Shah's ability to govern.
} 


\section{The impact of ideology and culture}

After the ousting of the modernist dictator Pahlavi I. (1921-1941) by the Allied Forces, Iran witnessed in the first decade of the rule of the new monarch Pahlavi II. a remarkable political opening and, subsequently, a mushrooming of political parties. Whereas the leftist forces mainly gathered around the Moscow-friendly communist party Hezb-e tudeh-ye Iran (the People's Party of Iran, hereinafter: the Tudeh Party), Mohammad Mosaddeq could integrate the nationalist-liberal forces under the umbrella of his Jebheh-ye Melli-ye Iran (the National Front of Iran, hereinafter: the National Front) to struggle for the nationalization of Iranian oil (industry). This lively political scene came, however, to an abrupt end as Mosaddeq was ousted from power and both the National Front and the Tudeh Party were banned, with their members becoming the target of a harsh persecution (Kinzer 2003: 194-195).

In the 1960s the regime faced the emergence of a new protest movement led by the clergy and articulated in religious terms. The protests were provoked by the Shah's plan to launch a series of land and social reforms, some of which (such as the expropriation of landlords and the introduction of women's right to vote) were regarded by the clerics as a violation of the sharia. As the conflict escalated, Ayatollah Ruhollah Khomeini, a vocal and sharp-tongued leading cleric, soon gained a surprisingly high degree of popularity. The conflict between the two parties led, in June 1963, to the upheaval of the $15^{\text {th }}$ Khordad, 1342 (June 5, 1963), which was heavy-handedly cracked down on by the regime. Ayatollah Khomeini, who had accused the Shah of conspiring with the USA and Israel to undermine Islam (Abrahamian 2013: 215), was deported to Turkey. These events turned June 5, 1963 into a milestone of Islamic resistance against the regime and Ayatollah Khomeini into its hero.

The clerical upheaval was paralleled by the rise of a nativist movement that was to impact Iranian politics for decades to come. In his path-breaking essay Gharbzadegi (westoxication) (1962), Al-e Ahmad (1923-69) criticized the alienation of Iranian society as a result of political and cultural domination by the West. And he regarded the remedy to the malaise of Iranian society as being a restoration of Iranian cultural identity which, in his eyes, was intrinsically Islamic (see also Amirpur 2017). ${ }^{17}$ Al-e Ahmad's critique of Westernization was in many regards a precursor to Said's Orientalism (1978).

The notion of Gharbzadegi was soon grasped by a whole generation of young Iranians including Ali Shariati - a holder of PhD in sociology from the Sorbonne in Paris. During his sojourn in Paris, Shariati was also exposed to and fascinated by a revolutionary discourse inspired by radical, anti-colonial movements in the world system, existentialism, and the revolutionary thoughts of Franz Fanon. ${ }^{18}$ Gifted in pen and tongue, Shariati blended all these inspirations into a kind of liberation theology in which Shiite Islam was depicted as a revolutionary ideology based on the notion that the believers were to fight all forms of injustice (Abrahami-

\footnotetext{
${ }^{17}$ Al-e Ahmad, an ex-communist and a co-founder of the so-called third-force movement, was a passionate follower of Mosaddeq and deeply depressed by the coup against his beloved prime minister. It was this shock as well as his disillusionment with the Soviet Union that led him to look for deeper causes of the problems of the Iranian society.

${ }^{18}$ In his writings, Fanon had masterly depicted the alienating impact of colonialism upon the colonized and had seen the remedy of this social-psychological malaise in violent liberation movements (which he saw as the manifestations of the revolutionary subject) (Abrahamian 1982a; Ghamari-Tabrizi 2004; Jahanbegloo 2017).
} 
an 1982a $)^{19}$ and that "revolutionary violence was legitimate as long as it paved the way for the emergence of a radical manifestation of Islamic moral order" (Jahanbegloo 2017: 22).

Shariati's depiction of world history as a Manichean battle between the oppressed and the oppressor perfectly represented the social split in Iran and, therefore, resonated with all social groups that regarded themselves as the oppressed. ${ }^{20}$

It was in this spirit of political radicalism that in the 1960s and 1970s there emerged several guerilla movements with either Islamic-Marxist or Marxist ideologies. ${ }^{21}$ These guerillas saw themselves as the pioneers of a mass revolution and tried to put cracks into the machinery of the regime by terrorizing the ruling elite. Many of these radicals were the offshoot of either the National Front or the Tudeh Party.

In the 1970s, radical notions of Shariati and the guerilla movements dominated political discourse. Therefore, as Khomeini stepped into the movement in 1978, he could easily tap into the sentiments of a whole generation of young men and women that could not wait for the destruction of the monarchic regime and its replacement by a utopian political order. Khomeini masterfully drew on the revolutionary vocabulary popularized by Shariati including concepts such as mostazafin (the oppressed), mostakberin (the arrogant, the oppressor) or even enqelab (revolution), which was not a known category in Shiite theology. Thus, Khomeini's proclaimed aim of ousting the Shah and installing an Islamic republic was generally perceived as a follow-up of Shariati's cause, even though he had never explicitly endorsed Shariati's interpretation of Shiism. Khomeini benefited not only from Shariati's remarkable ideological work, but also from peculiarities of Shiite culture, of which the following can be highlighted:

Firstly, Shiism is "heavily centered on the reverence of sacred, divine personalities and above all on its martyrs" (Gellner 1992: 17) and has, therefore, time and again proven to be a considerable emotional resource with the potential to be mobilized for political purposes. Secondly, the Shiite doctrine, according to which governance would be only legitimate if headed by a holy Imam, created a deep historical distrust among Shiite Iranians towards any state whatsoever. Calling Ayatollah Khomeini an Imam was apparently a deliberate decision by his men to create among the masses the illusion that Ayatollah Khomeini's rule would be equivalent to that of an infallible Imam. Thirdly, the religious masses have had for centuries a strong emotional attachment to their leading clerics: "Shi' ite scholars [...] are much better equipped to communicate with the masses in a state of political effervescence than are their Sunni counterparts" (Gellner 1992: 17). Fourthly, due to the Shiite religious tax of khoms, ${ }^{22}$ the grand aya-

\footnotetext{
${ }^{19}$ Interpreting the martyrdom of Imam Hussein, the third holy Imam of the Shiites and a grandson of the Prophet Muhammad, as a revolution against the rule of the Umayyad (661-750), Shariati regarded it as a duty of (Shiite) Muslims to stand up against any kind of injustice.

${ }^{20}$ The banner welcoming the arrival of Ayatollah Khomeini in Tehran with the famous Hafiz poem "as the devil leaves, the angel enters" was an unmatched expression of this Manichaean ideology of the good against the evil.

${ }^{21}$ The most influential of the guerilla movements were the Islamic-Marxist organization Sazeman-e Mojahedin-e Khalq-e Iran (The Organization of the Iranian People's Mojahedin), founded in 1965, and the Marxist organization Sazeman-e Cherik-hay-e Fada'i-ye khalq-e Iran (The Organization of the Iranian People's Self-sacrificing Guerillas), founded in 1971.

${ }^{22}$ According to the Shiite theology, every Muslim has the duty to pay a fifth of the annual profit of his business to a marja'-e taqlid (source of emulation - a grand ayatollah, whom the believers follow in theological questions). For a review of Schiism see Amirpur (2015).
} 
tollahs usually controlled immense amounts of financial resources and could therefore maintain an army of preachers distributed all over the country. Fifthly and finally, Khomeini could count on the unconditional obedience of the Jam iat-e Mo'talafeh-ye Eslami (The Islamic Coalition Organization), a well-organized "coalition of traditionalist guilds and other organizations based in Iran's bazaar community" (Gasiorowski 2008: 231). ${ }^{23}$

\section{The creeping dominance of the Islamists}

The 1979 Revolution was the result of a decades-long struggle for liberty. Therefore, an explanation is needed as to why the country ended up with the installation of a totalitarian, Islamist regime.

\section{The trigger of the revolution}

In 1977 the monarch initiated a modest degree of political opening by replacing the longruling Prime Minister Amir Abbas Hoveyda with the US-educated technocrat Jamshid Amoozegar. Thereupon several secular oppositional groups used different venues to express their dissent (see for example Sreberny/Mohammadi 1994: 104), with religious groups remaining predominantly silent. An inconspicuous incident, however, was to decisively change the dynamics of the reawakened protest movement.

On January 7, 1978 (Dey 17, 1356), Ayatollah Khomeini and his like-minded peers were attacked in a short article in the newspaper Ettellaat ${ }^{24}$ for their alleged liaison with foreign powers as well as their conservative worldview. As a reaction to these defamatory comments, theology students made protest gatherings at the theological seminary of Qom. The police intervention ended up with some protestors shot dead. Thereupon, on the commemoration of the $40^{\text {th }}$ day anniversary (Arba in) of the dead - a well-established Shiite tradition -, mass protests erupted in some cities, most notably in Tabriz. The repeated, harsh intervention by the police led to even more casualties. The news went viral around the country and set out an escalating cycle of mourning and violent repression with a 40-day rhythm.

The newspaper article not only triggered a landslide anti-government movement, it also initiated a transfer of the initiative of the movement from secular to religious forces (Keddie 2003: 225). Whilst the public sphere was strongly controlled by the surveillance institutions of the regime, a nationwide network of clergy functioned as the agents of a huge independent public sphere with an efficient and rapid internal communication channel across the country and into the farthest rural areas (Keddie 2003: 169).

\footnotetext{
${ }^{23}$ The Islamic Coalition Organization was founded during the clergy upheaval of the 1960s.

${ }^{24}$ Titled Iran va este 'mar-e sorkh va siah (Iran and the Red and Black Colonialism), the article claimed that Ayatollah Khomeini was at the service of "black" colonialism (referring to the UK) that together with "red colonialism" (referring to the Soviet Union) aimed at ruining the advancement of Iran. The article was signed by a certain Ahmad Rashidi Motlaq, which happened to be a pseudonym, as the article was written or commissioned by the then minister of information, Daryush Homayun (Keddie 2003: 225).
} 


\section{Ayatollah Khomeini's populism}

The revolution would have either not been successful or it would have taken another direction, if it were not for the elaborate strategy of Ayatollah Khomeini (Dabashi 1989). The opposition against the monarchic regime consisted of a coalition of different forces with divergent or even contradictory agendas. It was but for Ayatollah Khomeini's populism (Moghadam 1989) that so many different political factions accepted his leadership (Sheikhzadegan 2003): Shariati's followers, for instance, saw in him a reincarnation of their master; leftist forces admired him for his advocacy of revolution, deprived masses, republicanism, and anti-imperialism; and the liberal forces were attracted by his call for freedom, without scrutinizing whether he meant by azadi (freedom/liberation) a liberation from the monarchic regime and its Western allies or a liberal political order.

Major support for the Islamic revolution also came from traditional women. Despised in a rapidly Westernizing society for being ommol (old-fashioned), they now felt fully respected and welcomed to participate in what was believed to be a historical moment in the history of Iran. Feeling suddenly at home in public spaces, they turned overnight into political subjects struggling for the independence of the country and its purification from decadent Western influences.

\section{Power grab tactics of the Islamists}

After the revolution, Khomeini and his men deployed a subtle strategy to maximize and cement their power. Firstly, Khomeini co-opted leading members of the liberal organizations the National Front and the Freedom Movement (Nehzat-e Azadi) in the interim government. He thus used the immense popularity of the liberals to carry out the controversial referendums for the regime change (March 1979) and the new Constitution (December 1979), while profiting from their technocratic knowledge to run the country. Undoubtedly the pushing through of the new constitution was a milestone in the consolidation of the power of the clergy as it guaranteed far-reaching competences for them by entrenching, first and foremost, Khomeini's authoritarian doctrine of velayat-e faqih (Guardianship of the Islamic Jurist). Secondly, the Islamists masterfully mobilized the urban poor as violent mobs to intimidate any dissidence to their rule. Thirdly, they outmaneuvered the leftist groups by presenting themselves as advocates of the oppressed as well as by using a harsh rhetoric against the USA. Indeed, in November 1979 Khomeini supported the occupation of the US Embassy and the hostage-taking of its staff by the Islamist students; in doing so, he surpassed even the imagination of the most radical leftist groups. Fourthly and finally, they succeeded in pushing through their Islamist agenda by wiping out all factions that had helped them to oust the Shah, thereby playing off the factions against each other. As they set out to silence the liberals, including the grand ayatollah Shariatmadari (Milani 2008), they could count on the support of the leftists. And as they turned against the leftist groups, they profited from the rivalry between them. They therefore took on the organizations one at a time, thus persecuting the Moscow-friendly Tudeh Party at the very end and after it had helped them to silence all other organizations (Sheikhzadegan 2003). 
In order to legitimize their crackdown on the dissidents, "the Islamists made reference not only to the 'divine mission' they ascribed to themselves, but also to the defā'-e moqaddas ('holy defense') during the Iran-Iraq War (1980-1988)" (Sheikhzadegan 2017: 48).

\section{Synthesizing the findings}

In this section, the findings of the study as discussed in the preceding sections will be drawn upon to substantiate the two theses formulated in the introductory section of the contribution.

Thesis 1: The sparking of the revolution was a result of the dialectics of endogenic vs. exogenic and structural vs. cultural factors.

It is true that the Iranian revolution did not match the general pattern of revolutions being caused or catalyzed by military pressures from abroad (Skocpol 1982). Nevertheless, external economic, political and cultural influences - including the fluctuations of oil prices, political pressures by Carter, Western media and International civil-society actors, a zeitgeist of radicalism and a diffusion of Western/American lifestyles - all contributed, to varying degrees, to the sparking of the revolution, as they interacted with the internal mechanisms of the Iranian society.

Of special relevance to the revolution was indeed a forceful integration of Iran, in the aftermath of the military coup against the Prime Minister Mosaddeq, into the politicaleconomic structure of the world society (Bornschier 2008). Such a policy derailed the development of the country from its autochthonous path. So, an "uneven development" (Abrahamian 1982b: 419-449) based on a rentier state (Skocpol 1982) led to an ever deepening structural divide between the winners and the losers of the modernization process and ended up, in the aftermath of the 1973 oil crisis, in an economic crisis that the monarchic regime was not to survive (Mohaddesa/Pesaran 2012: 10). The crisis was even aggravated by two demographic factors:

On the one hand, a rejuvenated population was receptive to radical impulses from the world system - the more so, as it was frustrated by bleak economic conditions and by the lack of opportunities to articulate its concerns peacefully. On the other hand, a mass rural-urban migration intensified the supply crisis while creating new strata of urban poor that, alienated from modern urban life, were ready to follow any leader that would disrupt the status quo (Sheikhzadegan 2003).

Besides these structural factors, certain cultural and ideological peculiarities played into the process of the revolution, too. For instance, an emotional Shiite culture that glorified martyrdom, rejected any form of temporal state and revered its religious leaders and a revolutionary interpretation of Shiism elaborated by Shariati provided remarkable resources of defiance and resistance.

Thesis 2: the relevance of the strategies and counter-strategies of the Islamists and the monarchic regime to the dominance of the Islamists

It was indeed the publication of an insulting newspaper article against Ayatollah Khomeini that a) triggered the landslide protest movement and b) transferred the initiative of the movement from secular to religious forces. 
Thereupon, the Islamists masterfully resorted to the Shiite culture as well as to Shariati's religious-revolutionary ideology to mobilize the masses for a Manichean battle of good against evil - a cause that fit well in the deep social split of the society.

The absence of any legal and peaceful means for a public articulation of dissent left the Shah unaware of and insensitive to the grievances of different social groups and classes. That is why he was taken by surprise as a nation-wide upheaval erupted out of the blue. ${ }^{25}$ Being shocked by the extent of the movement, the Shah was soon entangled in a series of hasty decisions without being able to hide his fears. The indecisiveness of the Shah sharply contrasted with Khomeini's resolve and determination. Whereas the Shah, a broken man suffering from a deadly disease, was ready to make any concession to save his throne, Khomeini was not ready to make even the slightest concession and was admired by the whole nation, if not the whole world, for his steadfastness.

After the monarchic regime was toppled, the Islamists deployed a subtle strategy to eliminate all competing factions. As a first step, they co-opted some leading liberals to institutionalize their own power. They also outmaneuvered the leftists by resorting to social-radical and anti-American rhetoric and practice. Next, they set out to silence all factions by playing them against each other. Moreover, they used the Iran-Iraq war (1980-88) to mobilize the population around-the-flag and to denounce any resistance to their rule as a betrayal of Islam.

To sum it up, the Iranian Revolution emerged as a result of dialectics of endogenic vs. exogenic and structural vs. cultural/ideological factors. It was, however, due to the agency factor, namely the strategies and the degree of determination of both sides of the conflict (the Shah vs. the Islamists) that the revolution evolved into an Islamist regime. Finally, the relevance of contingent factors - in the sense of stochastic events (such as the exile of Khomeini to Paris or the publication of the small anti-Khomeini newspaper article) - cannot be dismissed.

\section{Concluding remarks}

Iran's encounter with modernity was a painful one, to say the least. As its geopolitical position and rich natural resources rendered it a spot of interest among superpowers, it witnessed recurrent, imperialist interventions into its internal affairs. Nevertheless, it was not always external pressure that destroyed the aspirations of Iranians for democracy and rule of law. On the contrary, Jimmy Carter's Human Rights policy could have been a real chance to introduce a liberal political order that would even go beyond the democratic experiences of the Mashruteh Revolution (1905-11) or Mosaddeq's era to include the most recent achievements in individual rights. Given the existence of popular liberal organizations like the National Front or the Freedom Movement and an influential liberal cleric like Ayatollah Shariatmadari, liberalism had a viable chance of at least imprinting itself on the new political order. However, the structural, cultural and political tensions caused by a half century of authoritarian modernism, a rentier state alienated from civil society, a young population receptive to a radical zeitgeist, and an army of power-driven Shiite clergy led to the rise of a new authoritarian regime based on an Islamist ideology. Rejoicing their liberation from the yoke of imperialism,

\footnotetext{
${ }^{25}$ For a discussion of unanticipated revolutions see Kuran $(1989 ; 1991)$.
} 
the Iranians soon came to realize that national sovereignty was by no means the sufficient, albeit necessary, condition for liberty. The reformist movement that arose during the 1990s out of the ashes of liberalism is an example of this insight.

\section{References}

Abrahamian, Ervand (1982a). Ali Shariati: Ideologue of the Iranian Revolution. MERIP REPORTS 102 - Islam and Politics, Volume: 12, http://www.merip.org/mer/mer102. Last access 08.11.2017.

Abrahamian, Ervand (1982b). Iran Between Two Revolutions. Princeton, N. J.: Princeton University Press.

Abrahamian, Ervand (1989). Radical Islam: The Iranian Mojahedin. London: I. B. Tauris.

Abrahamian, Ervand (2001). The 1953 coup in Iran. Science \& Society, 65(2), 182-215.

Abrahamian, Ervand (2013). The Coup: 1953, the CIA, and the Roots of Modern U.S.-Iranian Relations. New York and London: The New Press.

Afary, Janet and Kevin B. Anderson (2010). Foucault and the Iranian revolution: Gender and the seductions of Islamism. Chicago: University of Chicago Press.

Amirpur, Katajun (2015). Der schiitische Islam. Stuttgart: Reclam.

Amirpur, Katajun (2017). Constructing and Deconstructing Othering - Polycentrism versus Westoxication in Iran. In: Sheikhzadegan, Amir and Astrid Meier (eds.). Beyond the Islamic Revolution: Perceptions of Modernity and Tradition in Iran before and after 1979 (60-85). Reihe "Welten des Islams", Schweizer Asiengesellschaft, Berlin: De Gruyter.

Arjomand, Said A. (1988). The turban for the crown: The Islamic revolution in Iran. Studies in Middle Eastern History. New York, Oxford: Oxford University Press.

Ashraf, Ahmad (1989). Bazar III. Socioeconomic and Political Role, Encyclopcedia Iranica Online, http://www.iranicaonline.org/articles/bazar-iii. Accessed on 12.05.2018.

Bonine, Michael E. (1989). Bazar I. General, Encyclopeedia Iranica Online, http://www.iranicaonline.org/articles/bazar-i. Accessed on 12.05.2018.

Bornschier, Volker (2008). Weltgesellschaft: Grundlegende soziale Wandlungen. Zürich: LVB.

Boroujerdi, Mehrzad (1996). Iranian intellectuals and the West: The tormented triumph of nativism. Syracuse, New York: Syracuse University Press.

Brown, Seyom (1994). The faces of power: constancy and change in United States foreign policy from Truman to Clinton. New York: Columbia University Press.

Cardoso, Fernando H. and Enzo Faletto (1979). Dependency and Development in Latin America. Berkeley: University of California Press.

Dabashi, Hamid (1989). By what authority? The formation of Khomeini's revolutionary discourse, 1964-1977. Social Compass, 36 (4), 511-538.

Daneshkhu, Scheherazade (2004). The political economy of industrialisation in Iran, 1973-1978. PhDThesis (London School of Economics and Political Science, UK), http://etheses.lse.ac.uk/2794/1/U615743.pdf. Last access 06.04.2018. 
Davies, James C. (1962). Towards a theory of revolution. American Sociological Review, 27(1), 5-19.

Farhi, Farideh (1990). States and Urban-Based Revolutions: Iran and Nicaragua. Urbana: University of Illinois Press.

Floor, Willem (1989). Bāzār II. Organization and Function, Encyclopædia Iranica Online, http://www.iranicaonline.org/articles/bazar-ii. Accessed on 12.05.2018.

Foran, John (1990). A Theory of Third World Social Revolutions: Iran, Nicaragua and El Salvador Compared. Paper presented at the meetings of the International Sociological Association, Madrid.

Foran, John (1993). Theories of revolution revisited: Toward a fourth generation? Sociological Theory, $11(1), 1-20$.

Gasiorowski, Mark (2008). Government and Politics. In: Curtis, Glenn E. and Eric Hooglund (eds.). Iran, a country study. Fifth edition. Washington D.C.: The US Government Printing Office, 205254.

Gellner, Ernest (1992). Postmodernism, reason and religion. London and New York: Routledge.

Gerami, Shahin (1989). Religious Fundamentalism as a Response to Foreign Dependency: the Case of the Iranian Revolution. Social Compass, 36(4), 451-468.

Ghamari-Tabrizi, Behrooz (2004). Contentious Public Religion: Two Conceptions of Islam in Revolutionary Iran: Ali Shariati and Abdolkarim Soroush. International Sociology, 19 (4), 504-523.

Goldstone, Jack A. (1980). Theories of Revolution: The Third Generation. World Politics, 32 (3): 42553.

Goldstone, Jack A. (1982). The comparative and historical study of revolutions. Annual Review of Sociology, 8(1), 187-207.

Goldstone, Jack A. (1986). Revolutions and superpowers. In: Jonathan R. Adelman (ed.). Superpowers and Revolution. New York: Praeger, 38-46.

Goldstone, Jack A. (2001). Toward a Fourth Generation of Revolutionary Theory. Annual Review of Political Science, 4(1), 139-87.

Hourcade, Bernard (1983). Migrations intérieures et changement social en Iran. Méditerranée, 50(4), 63-69.

Hourcade, Bernard (1993). The Land Question and Islamic Revolution in Iran (translated by Afshin Matin-Asghari). South Asia Bulletin, XIII(1\&2), 134-147.

Ingold, Ingmar (2016). Vom Anfang und Ende der Revolution: eine legitimitätstheoretische Untersuchung unter besonderer Berücksichtigung der Revolutionen in Mexiko, China und Iran. Serie: Revolutionen in Geschichte und Gegenwart; Band 2, Baden-Baden: Nomos.

Jahanbegloo, Ramin (2017). Intellectuals and Society in Iran since 1953. In: Sheikhzadegan, Amir and Astrid Meier (eds.). Beyond the Islamic Revolution: Perceptions of Modernity and Tradition in Iran before and after 1979. Reihe "Welten des Islams", Schweizer Asiengesellschaft, Berlin: De Gruyter, 17-30.

Käufeler, Heinz (1988). Modernization, legitimacy and social movement: a study of socio-cultural dynamics and revolution in Iran and Ethiopia. Zürich: Ethnologisches Seminar der Universität Zürich. 
Keddie, Nikki R. (2003). Modern Iran: Roots and Results of Revolution. New Haven and London: Yale University Press.

Kinzer, Stephen (2003). All the Shah's Men: An American Coup and the Roots of Middle East Terror. Hoboken NJ: John Wiley \& Sons.

Kissinger, Henry (1979). The White House Years. Boston: Little, Brown and Co.

Kuran, Timur (1989). Sparks and prairie fires: A theory of unanticipated political revolution. Public choice, 61(1), 41-74.

Kuran, Timur (1991). Now out of never: The element of surprise in the East European revolution of 1989. World politics, 44(1), 7-48.

Kurzman, Charles (1996). Structural opportunity and perceived opportunity in social-movement theory: the Iranian revolution of 1979. American Sociological Review, 61(1), 153-170.

Looney, Robert E. (1973). The Economic Development of Iran: A Survey with projections to 1981. New York: Praeger.

Looney, Robert E. (1982). Economic Origins of the Iranian revolution. New York: Pergamon Press.

Looney, Robert E. (1986). Origins of pre-revolutionary Iran's development strategy. Middle Eastern Studies, 22(1), 104-119.

Milani, Abbas (2008). Eminent Persians: Men and Women Who Made Modern Iran, 1941-1979. Vol. I. Syracuse, NY: Syracuse University Press.

Milani, Abbas (2011). The Shah. New York: Palgrave Macmillan.

Moghadam, Valentine M. (1989). Populist Revolution and the Islamic State in Iran. In: Boswell, Terry (ed.). Revolution in the World System, Greenwich, CT: Greenwood, 147-63.

Mohaddesa, Kamiar and M. Hashem Pesaran (2012). One Hundred Years of Oil Income and the Iranian Economy: A Curse or a Blessing? http://www.econ.cam.ac.uk/peoplefiles/emeritus/mhp1/wp12/100-Iranian-Oil-27-December-2012.pdf. Last access 06.04.2018.

Said, Edward (1978). Orientalism: Western Conceptions of the Orient. London: Routledge \& Kegan Paul.

Scharabi, Mohamed (1985). Der Bazar. Das traditionelle Stadtzentrum im Nahen Osten und seine Handelseinrichtungen. Tübingen: Wasmuth.

Schulze, Reinhard (1994). Die Geschichte der islamischen Welt im 20. Jahrhundert. Munich: C.H.Beck.

Sheikhzadegan, Amir (2003). Der Griff des politischen Islam zur Macht: Iran und Algerien im Vergleich. Bern: Peter Lang Verlag.

Sheikhzadegan, Amir (2005). Die iranische Revolution von 1979: Eine makrosoziologische Analyse. Asiatische Studien, 59(3), 857-878.

Sheikhzadegan, Amir (2017). The Trajectory of the 1953 Military Coup and the Course of Liberal Islam in Iran: A Sociological Analysis. In: Sheikhzadegan, Amir and Astrid Meier (eds.). Beyond the Islamic Revolution: Perceptions of Modernity and Tradition in Iran before and after 1979. Reihe "Welten des Islams", Schweizer Asiengesellschaft, Berlin: De Gruyter, 31-59.

Skocpol, Theda (1982). Rentier State and Shi'a Islam in the Iranian Revolution, Theory and Society 11(3), 265-283. 
Sreberny, Annabelle and Ali Mohammadi (1994). Small media, big revolution: Communication, culture, and the Iranian revolution. Minneapolis and London: University of Minnesota Press.

Tocqueville, Alexis de (1955). The old regime and the French revolution. Translated by S. Gilbert. Garden City, New York: Doubleday Anchor. 